\title{
Struktur Konstruksi Wacana Sufisme
}

\author{
Zaprulkhan \\ Fakultas Dakwah \\ IAIN Syaikh Abdurrahman Siddik Bangka Belitung \\ Bangka, Indonesia \\ zaprulkhan_zahra@yahoo.co.id
}

\begin{abstract}
Normatively, the structure of Sufi discourse construction comes from within the religion of Islam itself. According to Ibn Khaldun, Sufism comes from authentic Islamic law. The seeds originally came from the first generation of Muslims as the path of truth and guidance. Sufi approaches based on their consistency in the service of God, reluctant to worldly pleasures, abstain from the false delights, wealth, and position hunted by most humans, and busy solitude in worship to God. Therefore in Islam, there can be no spirituality without the aid of the Qur'an, which teaches man everything he can know or can learn, and which can lead people to the ideals that are the object of his creation. This article will elaborate the structure of the construction of Sufism discourse originating from Islam.
\end{abstract}

Keywords: structure, construction, sufism, Islam

\begin{abstract}
Abstrak
Secara normatif, struktur konstruksi wacana sufi berasal dari dalam agama Islam itu sendiri. Menurut Ibnu Khaldun, tasawuf berasal dari hukum Islam yang otentik. Benih-benih tersebut awalnya berasal dari generasi Muslim pertama sebagai jalan kebenaran dan bimbingan. Pendekatan sufi didasarkan pada konsistensi mereka dalam pelayanan kepada Tuhan, enggan untuk kesenangan duniawi, menjauhkan diri dari kesenangan palsu, kekayaan, dan posisi yang diburu oleh kebanyakan manusia, dan kesendirian yang sibuk dalam ibadah kepada Tuhan. Karena itu dalam Islam, tidak akan ada kerohanian tanpa bantuan Alquran, yang mengajarkan manusia segala hal yang dapat ia ketahui atau pelajari, dan yang dapat menuntun orang pada cita-cita yang menjadi objek ciptaannya. Artikel ini akan menguraikan struktur konstruksi wacana tasawuf yang berasal dari Islam.
\end{abstract}

Kata Kunci: struktur, konstruksi, tasawuf, Islam

\section{A. Pendahuluan}

"Spirit kesalehan Qurani telah mengalir ke dalam kehidupan dan beragam ekspresi seperti dalam bentuk zikir, para zahid, dan asketisi awal. Sufisme merupakan perkembangan yang alami berasal dari kecenderungan-kecenderungan yang menyatu dalam agama Islam awal ini 
dan selalu menekankan kecenderungan-kecenderungan tersebut sebagai aspek esensial jalan pencerahan". ${ }^{1}$

Apa yang diungkapkan oleh Spencer Trimingham pada abad ke-20 di atas tentang orisinal asal mula tasawuf telah dikonfirmasi oleh sejarawan besar Muslim, Ibn Khaldun. Dalam telaah historis-sosiologisnya, Ibn Khaldun menemukan bahwa tasawuf bersumber sacara autentik dari agama Islam. Benih-benih awalnya bersumber dari generasi Pertama umat Islam sebagai jalan kebenaran dan petunjuk. Pendekatan kaum sufi berdasarkan keistikomahan mereka dalam mengabdi kepada Tuhan, enggan kepada glamouritas semu duniawi, berpantang dari kelezatan palsu, kekayaan, dan kedudukan yang diburu oleh kebanyakan manusia, serta sibuk menyendiri dalam beribadah kepada Allah. ${ }^{2}$

Dengan nada lebih eksplisit, pakar tasawuf dari era kita, Seyyed Hossein Nasr menyatakan bahwa Al-Qur'an adalah sumber bukan hanya hukum, melainkan juga jalan atau thariqah. Kehidupan spiritual Islam yang mengkristal di kemudian hari dalam tarekat-tarekat sufi berawal dari Nabi, yang merupakan sumber dari segala keutamaan dan kebajikan spiritual yang ditemukan dalam jiwa Muslim. Akan tetapi, jiwa Nabi itu sendiri disinari oleh cahaya Allah sebagaimana diwahyukan dalam Al-Qur'an sehingga tepat sekali bila dikatakan bahwa wahyu Al-Qur'an adalah sumber dari tasawuf. Bukanlah suatu kebetulan bahwa, selama berabad-abad, kaum sufi telah menjadi tokoh-tokoh terdepan dan paling menonjol dalam menjelaskan dan mengomentari kandungan Al-Qur'an, dan bahwa sebagian karya terbesar dalam tasawuf seperti Matsnawi dari Jalal Al-Din Rumi sesungguhnya merupakan komentar atas Teks Suci.

Sebenarnya, hanya kaum sufi sajalah yang mampu menyingkapkan hijab mempelai langit ini, yakni Al-Qur'an, untuk menunjukkan sebagian dari kecantikan dan keindahannya, yang disembunyikan dari mata orang-orang yang asing dengannya. ${ }^{3}$ Sehingga di dalam jagad Islam, tidak mungkin ada spiritualitas tanpa bantuan dari Kitab itu, yakni Al-Qur'an, yang mengajarkan kepada manusia segala sesuatu yang dapat diketahuinya atau yang dapat dipelajari, serta yang dapat mengantar manusia menuju cita-cita yang menjadi tujuan penciptaannya. ${ }^{4}$

Karena itu dalam bab awal ini, kita akan mengeksplorasi tasawuf dan ruang lingkupnya dengan mengkaji pengertian tasawuf dan rukun-rukunnya, menelusuri siapa sebenarnya kaum sufi itu, menyibak sumber-sumber fundamental tasawuf, dan diakhiri dengan konklusi yang memberikan afirmasi positif bahwa tasawuf bersumber dari dalam agama Islam sendiri; sebagai dimensi batin dari pemaknaan sekaligus pengamalan Al-Qur'an dan Sunnah Nabi Saw.

1 J. Spencer Trimingham, The Sufi Order In Islam (New York:Oxford University Press, 1971), hlm. 2.

${ }^{2}$ Ibn Khaldun, Muqaddimah (Beirut-Libanon: Dar Al-Kotob Al-ilmiyah, 2003), hlm. 381.

${ }^{3}$ Seyyed Hossein Nasr (ed.), Insiklopedi Tematis Spiritualitas Islam Manifestasi, terj. M. Solihin Arianto, dkk (Bandung: Mizan, 2003), hlm. 10-11.

${ }^{4}$ Ibid., hlm. 12. 


\section{B. Makna Tasawuf Dan Rukun-Rukunnya}

Secara etimologis, para pakar teoritis tasawuf menguraikan berbagai asal usul istilah tasawuf. Dalam karya-karya mereka ditemukan akar kata istilah tasawuf meliputi beberapa istilah berikut ini. Pertama, dari kata ahl al-shuffah yakni para sahabat—yang tinggal di serambi masjid Nabi-yang sangat miskin. Ahl al-shuffah adalah istilah yang diterapkan kepada sekolompok orang (kurang lebih sembilan puluh orang) miskin dan tidak punya rumah yang hidup mengandalkan sedekah dari kaum muslim. Mereka tinggal di serambi masjid Nabi di Madinah yang merupakan saqifah, atau atap untuk berteduh yang terbuat dari pelepah dan daun kurma. ${ }^{5}$ Mereka termasuk kaum Muhajirin, orang-orang yang ikut hijrah dengan Nabi Saw dari Mekah ke Madinah, dan karena kehilangan harta, berada dalam keadaan miskin dan tidak mempunyai apa-apa.

Kedua, dari kata shaff, yakni barisan-barisan shaf ketika sembahyang. Sebab orang-orang yang kuat imannya dan murni kebatinannya itu, biasanya memilih sembahyang pada shaf yang pertama. ${ }^{6}$ Dalam kata shaf yang berarti barisan itu juga bisa berarti seakan-akan hati mereka berada dibarisan paling depan dalam muhadharah di hadapan Allah. ${ }^{7}$

Ketiga, dari kata shafw atau shafa yang berarti bersih atau suci. Para pengamal tasawuf adalah orang-orang yang disucikan dan kaum sufi adalah orangorang yang telah mensucikan diri mereka melalui latihan jiwa yang berat dan lama.

Keempat, dari kata shaufanah yakni sebangsa buah-buahan kecil berbulubulu yang banyak tumbuh di padang pasir Tanah Arab. ${ }^{9}$ Atau dari kata shuf yang berarti bulu domba atau kain yang terbuat daru bulu yaitu wol. Namun kain wol yang dipakai kaum sufi adalah wol kasar dan bukan wol halus seperti sekarang. Memakai wol kasar di waktu itu adalah simbol kesederhanaan dan kemiskinan. Lawannya ialah memakai sutra, oleh orang-orang yang mewah hidupnya di kalangan pemerintahan. Kaum sufi sebagai golongan yang hidup sederhana dan dalam keadaan miskin, tetapi berhati suci dan mulia, menjauhi pemakaian sutra dan sebagai gantinya memakai wol kasar. ${ }^{10}$

Berhubungan dengan kata shuf, Gulen melukiskannya secara menarik: Sufi berarti menempuh jalan Hakikat Muhammadiyah (salik thariq al-haqiqah alahmadiyah) yang mengenakan pakaian berbahan wol (shuf) yang menjadi simbol penafikan dunia, sikap tawadu' (rendah hati), ketenangan hati, dan ketentraman nurani. Ia selalu mencintai kecintaan kepada Tuhan (hubb al-mahabbah); tidak pernah menyampingkan cinta kepada Tuhan dan tidak pernah menyampingkan

\footnotetext{
${ }^{5}$ Muhammad Hisyam Kabbani, Tasawuf dan Ihsan, terj. Zaimul Am (Jakarta: Serambi, 2007), hlm. 176-177.

${ }^{6}$ Hamka, Tasawuf (Jakarta: Pustaka Panjimas, 1993), hlm. 79.

${ }^{7}$ Imam al-Qusyairy, Al-Risalah Al-Qusyairiyyah Fi Ilmi al-Tashawwuf (Beirut: Darul Khair, tt), hlm. 279.

${ }^{8}$ Harun Nasution, Falsafah dan Mistisisme dalam Islam (Jakarta: Bulan Bintang, 1973), hlm. 57.

${ }^{9}$ Hamka, Tasawuf, op.cit, hlm. 79.

${ }^{10}$ Harun Nasution, Falsafah, op.cit, hlm. 57-58.
} 
para pecinta Tuhan; dan ia tidak pernah peduli kepada dunia yang ada di hadapannya serta tidak pernah menghadapkan wajah kepada hasrat duniawi.

Kebiasaan para sufi mengenakan kain wol (shuf), serta menisbahkan mereka kepada jenis kain ini terjadi disebabkan kain wol memang mampu menampilkan kondisi dan tingkatan mereka. Selain itu juga karena kain wol merupakan pakaian para anbiya, para pengikut mereka, dan juga pakaian orangorang yang membaktikan jiwa mereka hanya untuk beribadah. Jadi, kalau memang benar kain wol (shuf) adalah jenis kain yang biasa dikenakan oleh para nabi dan para sahabat mereka, maka kata "sufi" (shufi) memang benar-benar berasal dari kata ash-shuf yang berarti "wol". ${ }^{11}$

Terakhir, dari kata shopos yang berarti hikmat. ${ }^{12}$ Bagi sebagian pakar tasawuf, kata shuf yang berarti bulu wol merupakan yang paling banyak diterima sebagai akar etimologi tasawuf dan sufi. ${ }^{13}$ Namun bagi sebagian pakar yang lain, istilah tasawuf dan sufi lebih tepat dinisbahkan kepada kata shafw atau shafa yang berarti kesucian. ${ }^{14}$

Terlepas dari berbagai perbedaan makna etimologis tasawuf tersebut, mari kita melihat beberapa pengertian tasawuf secara langsung dari para empu sufi dan maestro tasawuf agar memperoleh pengertian yang holistik. Imam Junaid mengungkapkan bahwa tasawuf adalah menyelamatkan hati dari mengikuti emosi kemanusiaan, menjauhi akhlah-akhlak yang alami, memadamkan sifat-sifat kebiologisan, menjauhi berbagai ajakan jiwa, berhubungan secara erat dengan pengetahuan-pengetahuan hakikat, melakukan sesuatu yang bernilai luhur, menasihati manusia, memenuhi perjanjian secara hakiki dengan Allah Swt, dan mengikuti syariat Rasulullah Saw. ${ }^{15}$

Imam Junaid juga diakui begitu piawai membuat suatu definisi tentang tasawuf yang dipungutnya dari keunikan karakter-karakter agung para Rasul Tuhan yang disebut dalam Al-Qur'an yaitu: Tasawuf didirikan atas delapan kualitas yang dicontohkan oleh delapan orang Rasul: kemurahan hati Ibrahim, yang mengorbankan putranya; kepasrahan hati Ismail, yang taat kepada perintah Tuhan dan memberikan hidupnya yang paling berharga; kesabaran Ayyub, yang dengan sabar menanggung penderitaan akibat luka-luka boroknya dan menanggung kecemburuan Yang Maha Pengasih; perlambangan Zakariyya, yang kepadanya Tuhan berfirman: 'Engkau jangan berbicara kepada manusia selama tiga hari kecuali dengan tanda-tanda (isyarat) (QS. 3: 37), dan juga, 'Ketika ia berdoa kepada Tuhannya dengan suara yang berbisik lembut' (QS. 19: 3); dan keasingan Yahya, ia sebagai seorang asing di negerinya sendiri dan merasa terasing bagi sanak keluarnyanya, yang di tengah-tengah mereka ia hidup; perjalanan ruhani Isa,

${ }^{11}$ Muhammad Fethullah Gulen, Tasawuf Untuk Kita Semua, terj. Fuad Syaifuddin Nur (Jakarta: Republika, 2013), hlm. 18.

${ }^{12}$ Ibid., hlm. 57.

13 Ibid., hlm. 58, lihat Abu Nashr as-Sarraj, Al-Luma'. Terj. Wasmukan dan Samson Rahman (Surabaya: Risalah Gusti), hlm. 46

${ }^{14}$ Al-Hujwiri, Kasyful Mahjub, terj. Suwardjo Muthary dan Abdul Hadi (Bandung: Mizan, 1992), hlm. 40.

${ }^{15}$ Amir An-Najar, Psikoterapi Sufistik, terj. Ija Suntana (Jakarta: Hikmah, 2004), hlm. 186. 
yang dengan begitu rupa meninggalkan (kemewahan) benda-benda duniawi sehingga ia hanya menggunakan sebuah cangkir dan sebuah sisir-cangkir itu ia lemparkan apabila ia melihat seseorang yang minum dengan telapak tangannya, dan sisir itu dibuang apabila ia melihat orang lain menggunakan jari-jarinya untuk menyisir rambutnya; pakaian bulu domba yang digunakan oleh Musa, jubahnya terbuat dari bulu-bulu binatang itu; dan kefakiran Muhammad, yang kepadanya Tuhan telah menyampaikan kunci dari semua perbendaharaan harta yang ada di permukaan bumi, dan berkata: 'Jangan susahkan dirimu, tapi nikmatilah setiap kemewahan dengan menggunakan semua harta kekayaan ini; dan ia menjawab: "Wahai Tuhan, aku tidak menginginkan itu semua; berilah aku kenyang satu hari dan lapar satu hari. ${ }^{16}$

Sedangkan Ali bin Bundar Al-Syarafi berkomentar tentang tasawuf: Altashawwuf isqath al-ru'yat li- 'l-haqq zhahiran wa batinan (Tasawuf adalah begini. Bahwa sufi tidak boleh memandang lahiriah dan batiniahnya sendiri, melainkan harus memandang semuanya sebagai milik Tuhan). Jadi, jika kamu melihat segi lahir, kamu akan mendapatkan sebuah tanda lahiriah dari rahmat Allah, dan, seperti yang engkau lihat, tindakan-tindakan lahiriah tidak akan punya berat, sekalipun seberat sayap ngengat, di sisi rahmat Allah, dan kamu akan berhenti memandang dari segi lahir; dan jika kamu melihat segi batin, kamu akan menjumpai sebuah tanda batiniah dari pertolongan Allah, dan seperti yang kamu lihat, tindakantindakan batiniah tidak akan seberat biji sawi pun jika dibandingkan dengan pertolongan Tuhan, dan kamu akan berhenti memandang segi batin, dan akan melihat bahwa semuanya milik Tuhan; dan bilamana kamu melihat bahwa semuanya milik Tuhan, kamu akan melihat bahwa dirimu sendiri tak punya apaapa. ${ }^{17}$

Sementara itu, Abu Nasr as-Sarraj memandang tasawuf sebagai ilmu tertinggi dari berbagai ilmu lainnya, seperti ilmu riwayah, atsar, akhbar, fikih dan hukum, serta ilmu kias. Bagi Sarraj, tasawuf adalah ilmu hakikat, ilmu muamalah dengan Allah dan mujadalah, ikhlas dalam taat dan menghadapkan diri kepada Allah Azza wa Jalla dengan sepenuhnya. Menyerah dengan sepenuh jiwa kepada Allah dalam segala waktunya. Bersih niat dalam tujuan dan keinginan, membersihkan rahasia hati dari segala penyakit hati, merasa cukup dengan Sang Pencipta langit. Mematikan nafsu dengan cara melawan segala kemauannya, jujur dalam berbagai kondisi dan kedudukan spiritual, memiliki adab dan kesopanan di hadapan Allah, baik dalam rahasia hati maupun yang lahiriah dalam segala langkah, merasa cukup untuk mengambil bekal ketika dalam kondisi sangat membutuhkan, berpaling dari dunia dan meninggalkan apa yang ada di dalamnya demi mencari tingkatan yang tinggi di sisi Allah Swt, dan bisa mencapai kemuliaan-kemuliaan di sisi Allah Swt. ${ }^{18}$

Akan tetapi, sebagian master sufi menghubungkan makna tasawuf dengan manifestasi akhlak sejati. Abul Hasan Nuri menyatakan:Laysa al-tashawwuf

\footnotetext{
${ }^{16}$ Al-Hujwiri, Kasyful Mahjub, op.cit, hlm. 48.

${ }^{17}$ Ibid., hlm. 49

${ }^{18}$ Abu Nashr as-Sarraj, Al-Luma', op.cit, hlm. 750.
} 
rusuman wa-la 'uluman wa-la-kinnahu akhlaqun (Tasawuf tidak terdiri atas praktik-praktik dan ilmu-ilmu, tapi ia adalah moral/akhlak), yakni jika ia terdiri atas praktik-praktik, ia bisa dilakukan melalui usaha, dan jika ia terdiri atas ilmuilmu, ia bisa diperoleh melalui pelajaran: karenanya ia akhlak, dan tidak dapat diperoleh sampai engkau menuntut dari diri engkau sendiri prinsip-prinsip moral, dan membuat tindakan-tindakan sesuai dengan prinsip-prinsip moral itu, dan memenuhi tuntutan-tuntutannya. Perbedaan antara praktik-praktik (rusum) dan moral (akhlaq) begini, bahwa praktik-pratik adalah tindakan-tindakan seremonial yang maujud dari motif-motif tertentu, tindakan-tindakan yang tidak memiliki realitas, sehingga bentuknya berlainan dengan ruhnya, sementara akhlak adalah tindakan-tindakan terpuji tanpa upacara atau motif, tindakan-tindakan yang tidak memiliki pretensi, sehingga bentuknya selaras dengan ruhnya. ${ }^{19}$

Demikian pula Abu Muhammad Murta'isy mengatakan: Al-tashawwuf husn al-khulq (Tasawuf adalah watak yang baik). Hal ini ada tiga macam: pertama, kepada Tuhan, dengan memenuhi perintah-perintah-Nya tanpa kemunafikan; kedua, kepada manusia, dengan menghormati yang lebih tua dan berlaku kasih sayang kepada yang lebih muda dan berbuat adil terhadap sesama, dan dengan tidak mencari balasan dan keadilan dari segenap orang pada umumnya; dan ketiga, kepada diri sendiri, dengan tidak menuruti hawa nafsu dan setan. Barang siapa yang membuat dirinya benar dalam tiga tiga perkara ini, adalah seorang yang berwatak baik. ${ }^{20}$

Dalam konteks ini, kiranya sangat menarik bila kita menyimak juga uraian Syekh Abdul Qadir al-Jilani yang amat unik tentang tasawuf. Al-Jilani mengurai makna tasawuf dari huruf-huruf yang ada dalam kata tasawuf itu sendiri yang meliputi empat huruf hijaiyah yaitu, $T a$ ', Shad,Waw, dan $F a^{\prime}$ yang bagi para ahli tasawuf masing-masing huruf tersebut memiliki makna tersendiri.

Huruf $T a$ ' berasal dari kata tawbah (tobat) yang terbagi kepada dua bagian, yaitu: tobat zahir dan tobat batin. Tobat zahir adalah beranjaknya seseorangdengan seluruh organ lahiriahnya-dari perbuatan-perbuatan dosa menuju perbuatan-perbuatan taat; dari segala kemungkaran menuju kepatuhan, baik berupa perkataan mau pun perbuatan. Adapun tobat batin adalah beranjaknya seseorangdengan seluruh organ batiniahnya-dari segala kemungkaran menuju kepatuhan, guna untuk menjernihkan hatinya. Jika hal ini telah terlaksana dengan baik, maka sempurnalah posisi huruf $t a$ ' pada diri yang bersangkutan, dan para sufi menyebut orang itu dengan 'orang yang bertaobat'.

Huruf shad berasal dari kata shafa (kejernihan) yang juga terbagi dari dua bagian, yaitu kejernihan hati dan kejernihan nurani. Kejernihan hati maksudnya adalah jernihnya hati seseorang dari kotoran-kotoran yang bersarang di dalamnya akibat dari adanya keberlebihan dalam hal mengkonsumsi makanan-makanan dan minuman, banyak bicara, banyak tidur, dan banyak memperhatikan masalahmasalah duniawi seperti berlebihan dalam hal mencari penghidupan, berjima'

\footnotetext{
${ }^{19}$ Al-Hujwiri, Kasyful Mahjub, op.cit, hlm. 50.

${ }^{20}$ Ibid., hlm. 51.
} 
dengan istri, cinta terhadap anak dan keluarga, serta larangan-larangan psikologis lainnya.

Kejernihan hati ini hanyalah bisa diperoleh dengan jalan melanggengkan zikir terhadap Allah melalui talqin yang pada awalnya diucapkan dengan bersuara sampai mendapatkan posisi al-haqiqah (kedudukan spiritual yang menegaskan berbagai efek dari sifat-sifat hamba dengan sifat-sifat Allah, sehingga sifat-sifat itu mewarnai kehidupannya). Allah Ta'ala berfirman: "Sesungguhnya orang-orang yang beriman adalah orang-orang yang bergetar hatinya apabila disebut nama Allah" (QS. Al-Anfal 8: 2), atau takutlah hatinya.

Rasa takut itu muncul setelah hati terjaga dari tidur kelalaian, digosok, dan diukir padanya gambar-gambar kegaiban berupa kebaikan dan kejahatan. Para sufi mengatakan, 'Orang alim mengukir, sedangkan orang arif menggosok'. Sedangkan kejernihan nurani adalah dengan jalan menghindari perhatian dan rasa cinta terhadap segala selain Allah Ta'ala dengan cara melanggengkan Nama-nama Tauhid dengan lisan nurani. Jika penjernihan itu telah sempurna pada diri seseorang, maka sempurnalah posisi huruf ash-shad dalam dirinya.

Huruf Waw berasal dari wilayah (kewalian). Ia muncul setelah penjernihan hati dan nurani. Allah Ta'ala berfirman, "Ingatlah, sesungguhnya wali-wali Allah tidak ada kekhawatiran pada diri mereka dan tidak pula mereka bersedih hati" (SQ. Yunus 10: 62). Kewalian ini pada akhirnya akan menjadikan seseorang menjadi berakhlak dengan akhlak Allah Ta'ala. Rasulullah Saw bersabda: "Berakhlaklah kalian dengan akhlak Allah". Maksudnya, bersifatlah dengan sifatsifat Allah Ta'ala dan tinggalkanlah sifat-sifat kemanusiaan, sebab jubah kehormatan sifat-sifat Allah itu baru bisa didapatkan setelah dibuangnya sifat-sifat kemanusiaan. Allah Ta'ala berfirman dalam hadis Qudsi, "Jika Aku telah mencintai seorang hamba, maka Aku menjadi pendengaran, penglihatan, tangan, dan lidah baginya. Dengan-Ku dia mendengar, melihat, memukul, berbicara, dan berjalan". Dengan demikian, sempurnalah posisi huruf waw.

Huruf $\mathrm{Fa}^{\prime}$ berasal dari fana'fillah (peniadaan diri dalam Allah) dari segala selain Allah. Jika sifat-sifat manusiawi telah tiada, maka yang ada adalah sifat-sifat Keesaan Transenden yang tidak meniada, tidak lenyap, dan tidak menghilang. Hamba yang telah mengalami fana' ini akan tetap bersama Tuhan Yang Mahaabadi dan keridhaan-Nya, dan hati hamba yang telah mengalaminya akan abadi bersama Rahasia Yang Mahaabadi dan Perhatian-Nya. ${ }^{21}$ Jika kefanaan ini telah sempurna, maka seorang sufi menjadi abadi bersama Yang Maha Benar untuk selamalamanya.

Adapun Syekhul Akbar, Mahaguru Ibn Arabi menulis bahwa dalam tasawuf ada empat tahap pengamalan dan pemahaman: syariah (hukum keagamaan eksoterik), thariqah (jalan mistik), haqiqah (kebenaran), dan ma'rifah (pengetahuan). Tiap tingkat dibangun berdasarkan tingkat sebelumnya.

Pertama adalah syariah, dasar dari tiga tahap selanjutnya. Dalam bahasa Arab, syariah berarti "jalan". Ia adalah jalan yang benar-sebuah rute perjalanan

${ }^{21}$ Abdul Qadir al-Jilani, Titian Mahabbah, terj. Ahmad Fadhil (Jakarta: Sahara, 2003), hlm. 74-77. 
yang baik, yang dapat ditempuh oleh siapa pun. Syariah berisikan ajaran moral dan etika yang dapat dijumpai di semua agama. Mayoritas para sufi adalah muslim, dan syariah yang secara tradisional menjadi dasar tasawuf juga berasal dari Islam. Syariah memberi kita petunjuk untuk hidup secara tepat di dunia ini. Mencoba mengikuti tasawuf tanpa mengikuti syariat bagaikan membangun rumah berpondasikan pasir. Tanpa kehidupan teratur yang dibangun dari prinsip moral dan etika yang kuat, maka tidak ada mistisisime yang dapat berkembang.

Kedua, thariqah, yakni amalan tasawuf. Thariqah secara literal bermakna jalan tanpa rambu di padang pasir, yang ditempuh kaum Badui dari oasis ke oasis. Jalan ini tidak ditandai dengan rambu keluar yang jelas, laksana jalan bebas hambatan. Ia bahkan bukan jalan yang nyata. Untuk menemukan jalan Anda di padang pasir tanpa rambu ini, Anda perlu mengenal daerah tersebut dengan baik, atau Anda memerlukan seorang pemandu yang mengetahui arah yang dituju dan akrab dengan tanda-tanda setempat. Jika syariah merujuk pada amalan jasmaniah agama, maka thariqah merujuk pada amalan rohaniah tasawuf. Pemandu yang Anda butuhkan untuk menemukan jalan Anda tersebut adalah syekh. Bila syariah membuat penampilan luar kita bersih dan menarik, maka thariqah diciptakan untuk membersihkan dan menyucikan rohani kita. Satu sama lain saling mendukung.

Ketiga adalah haqiqah atau kebenaran. Haqiqah adalah makna terdalam dari praktik dan petunjuk yang ada pada syariat dan thariqah. Ia pengalaman langsung akan kebenaran gaib. Tanpa pemahaman yang didasari oleh pengalaman tersebut, maka kita ditakdirkan untuk taklid, meniru mereka yang telah mencapai tingkat haqiqah ini menegaskan dan memperkukuh praktik dua tingkat pertama. Sebelum mencapai tingkat haqiqah, seluruh praktik merupakan bentuk peniruan.

Keempat, ma'rifah atau pengetahuan. Ia adalah kearifan yang dalam atau pengetahuan akan kebenaran spiritual. Ia pengetahuan realitas yang hanya dicapai oleh segelintir orang. Ma'rifah adalah tingkatan para Nabi, Rasul, serta para sufi dan orang suci yang terkemuka.

Ibn Arabi menguraikan keempat tingkat ini. Pada tingkat hukum (syariah), "milikmu adalah milikku". Yakni, hukum keagamaan menjamin hak individu dan hubungan etika di antara manusia. Pada tingkat jalan sufi (thariqah), "milikku adalah milikmu, dan milikmu adalah milikku". Para darwis diharapkan memperlakukan sesama mereka seperti saudara — untuk membuka pintu rumah mereka, hati mereka, dan harta mereka satu sama lain. Pada tingkat kebenaran (haqiqah), "tidak ada milikku dan milikmu". Para sufi tingkat atas menyadari bahwa segalanya berasal dari Tuhan. Mereka hanyalah para pengemban amanah. Mereka tidak pantas memiliki apa pun. Mereka yang menyadari kebenaran telah melampaui rasa cinta terhadap kepemilikan dan penampakan luar secara umum, termasuk ketenaran dan kekuasaan. Pada tingkat pengetahuan (ma'rifah), "tidak ada aku dan kamu". Masing-masing pribadi menyadari bahwa segalanya adalah Tuhan, bahwa tidak ada satu pun dan tak ada seorang pun yang terpisah dari Tuhan. Inilah tujuan utama tasawuf. ${ }^{22}$

${ }^{22}$ Robert Frager, Hati, Diri, Jiwa, terj. Hasmiyah Rauf (Jakarta: Serambi, 1999), hlm. 1214. 
Selanjutya guru sufi kontemporer, Syekh Muahmmad Hisyam Kabbani menulis bahwa tasawuf adalah ilmu untuk mempelajari bagaimana membersihkan jiwa dari hasrat yang buruk, seperti dengki, tipu daya, riya', ingin dipuji, sombong, angkuh, marah, tamak, kikir, menghormati yang kaya dan menyingkirkan yang fakir, sebagaimana setiap orang harus membersihkan jasad lahiriahnya. Ilmu tasawuf mengajari seseorang agar melihat pada diri sendiri, membersihkannya sesuai dengan tuntunan Al-Qur'an dan Sunnah Nabi Saw, serta menghiasi diri dengan sifat-sifat sempurna (al-shifat al-kamilah). Termasuk dalam sifat-sifat mulia adalah tawbah (tobat), taqwa (takut kepada Allah), istiqamah (kukuh di jalan yang lurus), shidq (jujur dan benar), ikhlas (tulus), zuhud (menjauhi keduniaan), wara' (saleh), tawakkul (menggantungkan diri kepada Allah), adab (perilaku baik), mahabbah (cinta), dzikir (ingat), muraqabah (waspada), dan sifat-sifat baik lainnya yang terlalu banyak untuk disebutkan di sini.

Sebagaimana dalam ilmu hadis, dalam ilmu tasawuf pun terdapat klasifikasi kajian, baik tentang akhlak yang baik (akhlaq al-hasanah), yang wajib dikembangkan oleh setiap mukmin mau pun akhlak yang buruk (akhlaq dzamimah), yang harus dijauhi agar seseorang mencapai kondisi ihsan. Tasawuf berfungsi untuk menjernihkan hati, yang merupakan esensi paling berharga dan sumber hidup keislaman seseorang. Sebab, Islam tidak hanya meliputi tindakan lahir, tetapi juga aktivitas batin, sesuai dengan firman Allah, "Tinggalkanlah semиa dosa, baik yang lahir maupun yang batin" (QS. Al-An' am 6: 120), dan "Di antara orang beriman ada orang yang benar-benar menepati janjinya kepada Allah" (QS. Al-Ahzab 33: 23). Ayat kedua berarti bahwa tidak semua orang beriman termasuk dalam kelompok terpilih, yaitu orang yang "benar-benar menepati janjinya kepada Allah". Dengan kata lain, seorang mukmin belum tentu termasuk di antara kelompok orang yang memelihara janjinya hingga hatinya benar-benar bersih. Itulah kondisi ihsan, kesempurnaan perilaku yang disebutkan oleh Nabi Saw dalam hadis. Proses itulah yang dikembangkan dan diajarkan dalam ilmu tasawuf. ${ }^{23}$

Sedangkan ulama besar kharismatik dari Turki, Muhammad Fethullah Gulen menyatakan bahwa tasawuf adalah sebuah jalan terbuka menuju makrifat rabbaniyah dan amal yang selalu baik. Di dalamnya sama sekali tidak ada ruang untuk senda-gurau, ketidakpedulian, main-main dan kesia-siaan. Lagi pula bagaimana mungkin bisa demikian, sementara dasar dari tasawuf adalah penyerapan kesaksian makrifat uluhiyah yang dilanjutkan dengan menyematkannya di dalam hati, laksana lebah yang hilir-mudik dari sarangnya ke tempat bunga tumbuh; penyucian kalbu dari guncangan; penaklukan jiwa dari kencenderungan negatif; pengendalian sifat-sifat manusiawi dengan menutup sama sekali segala bentuk hasrat fisik-jasmaniah; selalu terbuka di hadapan nilai-nilai spiritual; penggunaan seluruh umur untuk mengikuti jejak langkah Sayyid al-Anam Muhammad Saw; pengosongan diri dari segala keinginan pribadi demi mengikuti keinginan Allah Swt; dan kesadaran penuh akan kehadiran Allah Swt yang diiringi

\footnotetext{
${ }^{23}$ Hisyam Kabbani, Tasawuf, op.cit, hlm. 28-29
} 
pengetahuan bahwa sikap menyandarkan diri kepada Al-Haqq Allah Swt adalah martabat yang tertinggi. ${ }^{24}$

Selain itu, Gulen juga menguraikan akar, subjek, manfaat, dasar, dan rukun-rukun tasawuf sebagai berikut:

Akar tasawuf adalah: Berpegang pada dasar-dasar agama sekuat-kuatnya, menjaga perintah serta larangan agama dengan cermat, dan menghindari dorongan nafsu sekuat tenaga dengan membiasakan kondisi lapar dan waspada.

Subjek tasawuf adalah: Mengangkat manusia ke derajat kehidupan spiritual-ruhaniah, menyucikan hati, dan mengarahkan seluruh lathifah ke tempat kembalinya yang sejati.

Manfaat tasawuf adalah: Mendorong manusia untuk menumbuhkembangkan unsur kemalaikatan (angelic qualities) yang ada dalam dirinya, serta mempertajam sensitivitas keimanan yang komprehensif dan orisinal sekali lagi secara nyata dan dengan segenap perasaan, lalu hidup dengannya.

Dasar tasawuf adalah: Memperdalam kesadaran ubudiyah yang dangkal dan mengasahnya dengan usaha sungguh-sungguh dalam ibadah dan ketaatan, serta menjadikannya sebagai elemen penting bagi karakter manusia, kedewasaan spiritual yang dianggap sebagai fitrah kedua bagi manusia, dan perhatian terhadap dua wajah dunia yang menghadap ke arah akhirat dan nama-nama baik (al-asma' al-husna) yang dimiliki Ilahi, sembari menutup rapat terhadap wajah dunia yang fana yang menghadap ke arah jati diri dan hawa nafsunya. ${ }^{25}$

Dasar dari tasawuf itu juga mencakup upaya menjaga adab-adab syariat secara lahiriah dan berdiri di atas adab-adab tersebut secara batiniah. Seorang salik yang terampil menggunakan kedua sayap ini akan dapat melihat hukum-hukum (ketetapan) dari batin pada apa yang tampak secara lahir, dan ia juga dapat merasakan dan hidup secara lahir dengan hukum-hukum (ketetapan) yang ada di dalam batin. Berkat adanya musyahadah dan sensitivitas semacam ini, maka ia akan selalu dapat menempuh perjalanannya dengan adab menuju tujuannya, tanpa pernah jauh dari jalan kebenaran karena ia selalu berada didekat jalan tersebut. ${ }^{26}$ Adapun rukun-rukun tasawuf dapat disusun peringkatnya sebagai berikut:

1. Pencapaian tauhid hakiki melalui jalan teoretik dan praktik.

2. Membaca serta mengobservasi perintah-perintah dari Hadrah Kekuasaan dan Kehendak Ilahi, di samping mendengar dan memahami Yang Terhormat firman Ilahi.

3. Memenuhi diri dengan mahabbah kepada Al-Haqq Allah Swt; melihat demi Dia kepada semua entitas dengan menganggapnya sebagai "persemaian ukhuwah"; serta melaksanakan interaksi yang baik dengan semua manusia, dan bahkan dengan segala sesutau.

4. Beramal dengan semangat al-itsar (mengutamakan orang lain) di setiap saat, dengan selalu mengutamakan kepentingan orang lain dibandingkan diri sendiri sesuai kemampuan.

\footnotetext{
${ }^{24}$ Muhammad Fethullah Gulen, Tasawuf Untuk Kita, op.cit, hlm. 3.

${ }^{25}$ Ibid., hlm. 3-4.

${ }^{26}$ Ibid., hlm. 2-3.
} 
5. Mengutamakan kehendak Ilahi di atas kehendak pribadi serta berusaha menggunakan seluruh usia untuk mendaki ke puncak "al-fana fi-Allah" (fana dalam Allah) dan "al-baqai bi-Allah" (kekal dengan Allah).

6. Terbuka terhadap al- 'isq (cinta), al-wajd (kerinduan spiritual), al-jadzb, dan al-injidzab (ekstase).

7. Mampu menembus apa yang ada di dalam hati melalui ekspresi wajah, dan mampu membaca berbagai rahasia Ilahiah yang terdapat pada tampilan kejadian-kejadian.

8. Melakukan ziarah ke tempat-tempat yang dapat mengingatkan kepada akhirat dengan niat perjalanan untuk mendapatkan semangat hijrah.

9. Merasa cukup dengan berbagai perasaan dan kenikmatan yang berada di dalam lingkup syariat, serta bertekad untuk tidak melangkah sedikit pun ke arah kawasan di luar syariat.

10.Terus bermujahadah dan berjuang untuk melawan sikap panjang anganangan (thul al-amal) yang akan menimbulkan dugaan-dugaan tak berkesudahan.

11.Tidak pernah melupakan—meski hanya sesaat—bahwa tidak ada keselamatan yang dapat diraih selain hanya melalui jalan keyakinan, keikhlasan, dan ridha Ilahi, walaupun amal yang dilakukan adalah demi berkhidmat pada agama dan untuk menghantarkan manusia menuju $\mathrm{Al}$ Haqq Allah Swt. ${ }^{27}$

\section{Siapakah Kaum Sufi Itu?}

Seseorang bertanya kepada Abu Hafs: "Siapakah sufi?"

Ia menjawab: "Seorang sufi tidak bertanya siapa sufi" ${ }^{28}$

Siapakah kaum sufi itu sesungguhnya? Di sini pun untuk melihat potret kaum sufi secara komprehensif, kita akan menyimak penuturan langsung dari para guru sufi dan pakar tasawuf sejak era klasik hingga kontemporer. Guru agung sufi abad ketiga Hijriyah, al-Harits al-Muhasibi mengungkapkan bahwa para sufi adalah manusia yang paling tenteram jiwanya sebab mereka selalu bersama Allah Swt. Mereka adalah makhluk yang paling berharga desah nafasnya, paling bercahaya jiwanya, paling tidak membutuhkan kekayaan, dan paling baik kehidupannya. Mereka adalah makhluk yang selalu bersedih atas sesuatu yang oleh manusia biasa disenangi dan selalu bahagia atas sesuatu yang oleh manusia biasa disedihkan. Yang dicari oleh para sufi adalah 'sesuatu' yang ditinggalkan oleh manusia biasa dan mereka lari terbirit-birit dari sesuatu yang dicari oleh manusia biasa, yaitu orang-orang yang lalai dan suka menipu. Para sufi merasakan keakraban ketika manusia merasa risau, sebab keakraban mereka adalah bersama Allah Swt sebagai penyempurnaan dalam munajat kepada-Nya. Hanya kepada Allah Swt mereka menyerahkan kebutuhan dan keperluannya. Mereka menjadikan

${ }^{27}$ Ibid., hlm. 4-5.

${ }^{28}$ Annemarie Schimmel, Dimensi Mistik Dalam Islam, terj. Sapardi Djoko Damono, dkk (Jakarta: Pustaka Firdaus, 2000), hlm. ix. 
Allah Swt sebagai perisai, pelindung, dan penjaga. Mereka percaya penuh kepadaNya, tidak kepada mahluk-Nya. ${ }^{29}$

Berikut ini gambaran Muhasibi tentang kaum sufi dalam salah satu karyanya, al-Washaya, ketika ia menuturkan pencariannya terhadap hakikat kebenaran yang berlabuh di pintu para kaum sufi:

Pada diri merekalah (kaum sufi) aku menemukan tanda-tanda takwa, warak, dan zuhud. Mereka lebih menyukai kehidupan akhirat ketimbang dunia. Aku menemukan bahwa ajaran dan nasihat mereka selaras dengan tindakan para mursyid; mereka senantiasa berkumpul untuk memberikan nasihat yang baik kepada umat, tidak mendorong siapa pun untuk mengingkari-Nya, dan menganjurkan mereka untuk tidak berputus asa mengharap rahmat-Nya. Mereka selalu terbuka dan sabar menghadapi kesulitan, meridhai takdir, dan mensyukuri segala nikmat. Mereka menjadikan segenap makhluk mencintai Tuhannya disertai penyesalan yang sempurna; mereka mengingatkan umat akan karunia dan anugerah-Nya; mendorong mereka untuk mengembalikan segala persoalan kepada-Nya, menyadari keagungan-Nya, serta berusaha memahami kitab-Nya dan sunah Nabi-Nya; menganjurkan mereka untuk memahami agama-Nya, mengetahui apa yang disukai dan tidak disukai-Nya, serta berhati-hati dan menghindari segala hal yang tidak berguna, menahan diri dari sikap berlebih-lebihan, tidak memedulikan perdebatan dan adu argumen, menahan diri dari fitnah dan laku aniaya, melawan hawa nafsu, dan melakukan introspeksi diri, mengontrol perasaannya, berhati-hati dalam makanan, pakaian dan semua keadaannya, menghindari segala yang meragukan, menghindari dorongan hawa nafsu birahi, rela dengan sedikit makanan, mengurangi segala hal yang tidak perlu, menjalani apa yang diperbolehkan, waspada terhadap Hari Pengadilan, takut akan Hari Kebangkitan, menyibukkan diri dengan urusan sendiri, keras terhadap dirinya sendiri, tetapi tidak bersikap keras kepada orang lain. Mereka sibuk dan khusuyuk beribadah, mengetahui banyak hal tentang hari akhirat dan gambaran tentang Hari Pengadilan beserta pahalanya yang sangat besar dan azabnya yang sangat menyakitkan. Itulah yang membuat mereka selalu cemas dan khawatir; itulah yang menjauhkan mereka dari kesenangan dan kenikmatan duniawi.

Mereka telah menjelmakan pola perilaku agama ini dan membuat garis ketakwaan yang tegas dengan cara yang membuat dadaku mengerut diliputi kekaguman. Aku semakin yakin bahwa perilaku beragama dan ketulusan warak merupakan samudera yang dalamnya tak dapat diukur manusia. Kini aku menyadari keagungan dan keutamaan mereka, memahami minat mereka, dan aku semakin yakin bahwa mereka adalah orang-orang yang bekerja keras menempuh jalan akhirat, pengikut sejati contoh yang ditunjukkan para rasul, sumber cahaya bagi mereka yang mencari penerangan, dan bimbingan bagi mereka yang mencari petunjuk. ${ }^{30}$

${ }^{29}$ Amir An-Najar, Psikoterapi Sufistik, op.cit, hlm. 5-6.

${ }^{30}$ Hisyam Kabbani, Tasawuf, op.cit, hlm. 68-70. 
Sedangkan Imam Junaid menyatakan, kaum sufi itu laksana bumi, segala macam bentuk kotoran dileparkan kepadanya, tapi tidak ada yang tumbuh dari dalamnya selain segala tumbuhan yang baik dan menyenangkan. Kaum sufi juga bagaikan bumi yang dilewati oleh kaum saleh mau pun para pendosa; kaum sufi juga seperti awan yang selalu berusaha memayungi segala sesuatu; Atau seperti hujan yang mampu melepaskan dahaga bumi persada. ${ }^{31}$

Sementara itu, Dzun Nun Al-Misri berkata: Al-shufi idza nathaqa bana nuthquhu 'an al-haqa'iq wa-in sakata nathaqat 'anhu al-jawarih bi qath' al'ala'iq, Sufi adalah yang bahasanya, ketika dia berbicara, adalah hakikat keadaannya, yakni dia tidak mengatakan sesuatu pun yang tidak ada pada dirinya, dan ketika dia berdiam diri, sikapnya menunjukkan keadaannya, dan keadaannya menyatakan bahwa dia telah memutuskan tali ikatan duniawi; yakni semua yang dia katakan berdasarkan prinsip yang benar, dan semua yang dia lakukan adalah keterpisahan yang penuh dari dunia (tajrid); ketika dia berbicara, pembicaraannya sepenuhnya tentang Kebenaran, dan ketika dia berdiam diri, tindakannya sepenuhnya "kefakiran" $($ faqr $){ }^{32}$

Sahabat karib Imam Junaid, Abul Hasan Nuri mengatakan: As-shufiyyat humu alladzina shafat arwahuhum fa-sharu fi al-shaff al-awwal bayna yadayi alhaqq, Sufi-sufi adalah mereka yang ruh-ruhnya terbebaskan dari pencemaran manusiawi, tersucikan dari noda jasmani, dan terlepas dari hawa nafsu, sehingga mereka menemukan ketenangan bersama Tuhan dalam barisan awal dan derajat yang paling tinggi, dan terbebas dari semuanya kecuali Tuhan. Dan dia juga mengatakan: Al-shufi alladzi la yamlik wa-la yumlak, Sufi adalah dia yang tidak memiliki apa pun dan tidak juga dimiliki oleh sesuatu pun. Ini menunjukkan hakikat pelenyapan (fana), karena seseorang yang kualitas-kualitasnya terlenyapkan, maka dia tidak memiliki dan tidak juga dimiliki, karena istilah "milik" hanya bisa dengan tepat dikenakan kepada benda-benda yang maujud. Maknanya ialah, bahwa sufi tidaklah membuat miliknya menjadi kebaikan di dunia ini atau kejayaan di akhirat, karena ia sama sekali tidak berada dalam pemilikan dan kendali dirinya sendiri: dia mencegah dirinya dari menginginkan kekuasaan atas orang-orang atau benda-benda yang lain, agar yang lainnya itu tidak bisa menginginkan kepasrahan darinya. Perkataan ini menunjuk kepada suatu rahasia dari sufi-sufi yang mereka sebut 'pelenyapan sempurna' (fana-yi kulli). ${ }^{33}$

Begitu pula Abu Muhammad Murta'isy mengatakan: Al-shufi la yasbiqu himmatuhu khathwatahu, sufi adalah dia yang pikirannya selaras dengan langkah kakinya, yakni dia yang sepenuhnya hadir; jiwanya ada di mana badannya ada, dan badannya ada di mana jiwanya ada, dan jiwanya ada di mana kakinya ada, dan kakinya ada di mana jiwanya ada. ${ }^{34}$

\footnotetext{
${ }^{31}$ Imam al-Qusyairy, Al-Risalah, op.cit, hlm. 281.

${ }^{32}$ Al-Hujwiri, Kasyful Mahjub, op.cit, hlm. 45.

${ }^{33}$ Ibid., hlm. 46.

${ }^{34}$ Ibid., hlm. 47.
} 
Sekitar awal abad kelima Hijriyah, Ali bin Utsman al-Hujwiri, dalam karya monumentalnya, Kasyful Mahjub, menguraikan makna shufi yang dibedakan dengan mutashawwif dan mustashwif. Seorang sufi adalah yang mati pada dirinya dan hidup oleh Kebenaran; ia bebas dari batas-batas kemampuan manusiawi, dan benar-benar telah sampai (kepada Tuhan). Mutashawwif adalah ia yang berusaha keras untuk mencapai tingkat ini dengan cara menundukkan hawa nafsu (mujahadat), dan dalam pencariannya ia meluruskan tingkah lakunya sesuai dengan teladan mereka (sufi-sufi). Mustashwif adalah ia yang membuat dirinya secara lahiriah serupa mereka (sufi-sufi) untuk sekedar mencari uang, kekayaan, kekuasaan, serta keuntungan-keuntungan duniawi, tapi sedikit pun tidak mempunyai pengetahuan tentang kedua hal ini. Karennya dikatakan: Al-mustashwif 'inda al-shufiyyat ka al-dzubab wa 'inda ghayrihim ka al-dzi'ab. Mustashwif, dalam pandangan para sufi, sehina lalat-lalat, dan kelakuan-kelakuannya hanya didasarkan ketamakan semata-mata; orang lain menganggapnya seperti seekor serigala, dan mulutnya tak terkendali (be afsar), karena ia hanya mengingkan secuil bangkai.

Maka dari itu, shufi adalah seorang yang manunggal (shahib wushul), mustashawwif adalah seseorang yang berpegang teguh pada prinsip-prinsip (shahib ushul), sedang mustashwif adalah seseorang yang suka berbuat sia-sia (shahib fudhul). Ia yang memiliki jiwa manunggal, tidak lagi mempunyai tujuan dan sasaran setelah mendapatkan tujuannya dan mencapai sasarannya; ia hanya memiliki prinsip menjadi teguh dalam "keadaan-keadaan" di jalan mistik, dan karenanya ia dengan tekun mencari rahasia-rahasianya; tapi ia yang cuma memiliki sifat suka berbuat sia-sia, kehilangan semuanya (yang patut dimiliki), dan ia duduk di pintu gerbang formalitas (rasm), dan dengan demikian ia terhijab dari hakikat (ma'ni), dan hijab ini membuat kemanunggalan dan prinsip tidak tampak olehnya. ${ }^{35}$

Selanjutnya beberapa dekade setelah Hujwiri, Imam Ghazali dalam karya otobiografi spiritualnya, Al-Munqidz Minadz-Dhalal, melukiskan dengan sangat ekspresif dan impresif tentang kemuliaan kaum sufi sekaligus metode dan akhlak mereka:

Ditengah-tengah khalwat (pengasingan)ku, tersingkaplah pengalamanpengalaman sufistik yang tidak mungkin dihitung dan diungkapkan secara rinci. Kadar yang bisa saya sebutkan untuk dipahami bahwa saya tahu secara meyakinkan kalau kaum sufi adalah orang-orang yang berada di jalan Allah secara khusus. Jalan mereka adalah jalan yang terbaik. Cara mereka adalah cara yang terbenar. Akhlak mereka adalah akhlak yang tersuci. Bahkan jika pikiran para cendekiawan, hikmah para ahli hikmah dan pengetahuan para ulama yang mengetahui rahasia-rahasia syariat dikumpulkan untuk mengubah jalan dan akhlak kaum sufi serta menggantikannya dengan yang lebih baik, mereka tidak akan menemukan jalan untuk itu. Karena semua gerak dan diam mereka, pada lahir dan batinnya, teradopsi dari lentera kenabian. Padahal tidak ada cahaya di muka bumi yang melebihi terang cahaya kenabian. Sesungguhnya pada waktu

${ }^{35}$ Ibid., hlm. 44. 
sadar mereka mampu menyaksikan malaikat dan ruh-ruh para Nabi sekaligus mendengar suara mereka. Kaum sufi juga dapat mengambil langsung berbagai pengetahuandan pemahaman diri mereka. ${ }^{36}$

Pada abad ketujuh belas Masehi, seorang sarjana dari Kashmir, Sirajuddin melakukan penelitian terhadap praktek-praktek kaum sufi dengan berkelana ke berbagai negara tetangganya, bahkan sampai ke Indonesia (Jawa), Cina, dan Gurun Sahara. Setelah selesai mengadakan riset di berbagai negara tersebut, Surajuddin melukiskan kaum sufi dengan indah dan memberi kita nasihat bagaimana caranya memahami mereka:

"Sufi adalah manusia sempurna; ketika ia mengatakan, 'Di antara bunga-bunga mawar, ada satu mawar dan di antara duri-duri, ada satu duri', ia sama sekali tidak bermaksud membicarakan perilaku sosial. Para sufi adalah penyair dan pencinta. Dilihat dari dasar ajarannya, mereka adalah pasukan, pelaksana dan tabib. Di mata para pengamat, mereka tampak seperti tukang sihir, mistikus, para pekerja seni yang tak terpahami. Bila Anda menghormati mereka sebagai seorang suci, Anda akan mendapat rahmat dari kesucian mereka. Namun bila Anda bergabung dengan jamaah mereka, Anda memperoleh rahmat dari jemaah mereka. Bagi mereka dunia ini adalah suatu perangkat untuk memperbaiki ummat manusia. Bila kita mengidentifikasi proses kreasi mereka yang sinambung, mereka sendiri adalah pencipta manusia sempurna lainnya. Di antara mereka ada yang membuka suara, namun ada juga yang berdiam diri, ada yang berjalan-jalan seperti gelisah namun ada yang duduk mengajar. Untuk memahami mereka, Anda harus menggunakan intelegensi intuitif, biasanya dengan menekan musuh bebuyutannya, yaitu intelegensi logis. Sebelum Anda memahami ketidaklogisan dan kesia-siaan perilaku mereka, sebaiknya jauhilah mereka kecuali untuk kebaktian tertentu, formal dan jelas". ${ }^{37}$

Pada penghujung abad ke-20 Masehi, guru sufi kontemporer, Idries Shah mewartakan kaum sufi dengan menukil seorang penuls wacana sufistik semasa: Sufi yang sempurna (tercerahkan) adalah manusia agung, mulia dan luhur. Melalui cinta, amal dan harmoni, ia telah mencapai tingkat keagungan paling tinggi. Semua rahasia terungkap baginya dan seluruh kehidupannya dikaruniai kekuatan magis. Dia adalah Penuntun dan Musafir di Jalan Keindahan, cinta, tahap-tahap pengalaman, kekuatan dan perwujudan tak terbatas. Dia adalah Penjaga kearifan paling kuno, Perintis mengungkap rahasia-rahasia terdalam. Dia adalah Sahabat penuh kasih yang mengangkat keberadaan kita dan membawa makna baru bagi kemanusiaan". 38

Menurut para ahli sufisme secara historis-sosiologis, tokoh utama yang dijuluki 'sufi' dalam sejarah Islam adalah seorang ahli zuhud bernama Abu Hasyim

\footnotetext{
${ }^{36}$ Imam Al-Ghazali, Al-Munqizh Minadh Dhalal (Libanon: Beirut,tt), hlm. 75.

${ }^{37}$ Idries Shah, Mahkota Sufi, terj. Hidayatullah \& Roudlon (Surabaya: Risalah Gusti, 2000),

${ }^{38}$ Ibid., hlm. 17.
} hlm. 18 . 
al-Kufi ${ }^{39}$ yang wafat di Baghdad pada tahun 150 Hijriyah. Jadi dapat dikatakan bahwa kata 'sufi' baru digunakan pada kurun kedua hijriyah atau sebelum berlalu dua ratus tahun dari hijrahnya Rasulullah Saw. Ini berarti bahwa penggunakan kata 'sufi' dengan pengertian seperti ini baru muncul setelah masa para sahabat Raasulullah dan tabi'in.

Tasawuf yang kita kenal sebagai sebuah manhaj melalui tokoh zuhud Abu Hasyim, yang sejak awal kemunculannya memang telah menjadi maslak bagi para pemilik kalbu dan ruh, selalu berjalan sesuai dengan nilai-nilai kesederhanaan dan kerendahan hati yang terdapat dalam kehidupan Rasulullah Saw dan para sahabat beliau yang mulia. Selain itu ia juga selalu mengambil posisi yang tegas terhadap dunia yang berhadapan dengan berbagai hal yang akan terjadi setelah kematian. ${ }^{40}$

Demikianlah, kita bisa menyimpulkan makna sufi dari para ahli tasawuf yang masyhur bahwa sufi berarti penempuh jalan menuju al-Haqq (as-salik ila alhaqq) yang mencapai tingkat kesucian pada kehidupan kalbu dan pada dimensi internalnya. Sufi juga berarti manusia al-Haqq (rajul al-haqq) yang sama sekali tidak memiliki klaim atas apa pun, karena dia selalu mengutamakan Allah al-haqq Subhanahu wa ta'ala berdasarkan ikhtiyarnya sendiri dan upayanya untuk menjernihkan dirinya dengan cara membersihkannya dari kotoran nafsu sampai akhirnya ia berhasil. ${ }^{41}$

\section{Kesimpulan}

Dari berbagai eksposisi di atas, menjadi jelas bahwa struktur konstruksi wacana sufisme mengalir dari dalam agama Islam itu sendiri secara autentik dengan menekankan aspek esoteris ketimbang aspek eksoteris. Demikianlah, karena tasawuf adalah jalan menuju ibadah yang pusat konsentrasinya adalah batin, dan selalu bergelut dengan aspek ruhaniah dari hukum-hukum syariat serta pengaruhnya terhadap hati, berikut kedalaman yang terdapat di dalam kalbu. Maka dibandingkan dengan jalan (maslak) yang lain, tasawuf adalah jalan yang paling dalam, bersifat laduniyyah, paling jauh jangkauannya, dan paling sukar dipahami. Tetapi meski demikian, tasawuf tetap memiliki tujuan dan sekaligus titik awal yang berasal dari Al-Kitab dan As-Sunnah serta tidak pernah menafikan semua jalan lain yang ada di dalam Islam.

Bahkan, sebagaimana halnya ilmu-ilmu syariat yang lain, tasawuf juga menegaskan esensi dari ilmu, makrifat, keyakinan, keikhlasan, ihsan, dan berbagai realitas lainnya, dengan mengandalkan sepenuhnya pada Al-Kitab, as-Sunnah, dan berbagai ijtihad lurus yang dilakukan oleh para salafushshalih. Dengan begitu, kehidupan spiritual Islam mendapatkan landasan ilmiahnya. Itulah kehidupan yang disandarkan pada landasan praktik yang berkaitan langsung dengan kondisi hati, seperi zuhudnya para ahli zuhud, ibadahnya para ahli ibadah, kepekaan spiritualnya pada ahli wara', kelembutan perasaan orang-orang yang ikhlas, cinta dan kerinduan

${ }^{39}$ Maulana 'Abd ar-Rahman Jami, Ensiklopedi Tokoh Sufi, terj. Kamran Asad Irsyadi dan Mata Nasrullah (Yogyakarta: Beranda, 2007), hlm. 3-5.

${ }^{40}$ Fethullah Gulen, Tasawuf Untuk Kita, op.cit, hlm. 19.

${ }^{41}$ Ibid., hlm. 17. 
para pencinta, dan ketajaman pandangan orang-orang fakir yang menyadari kelemahan serta kefakiran mereka di hadapan Allah. 


\section{DAFTAR PUSTAKA}

Al-Ghazali, Imam. Al-Munqizh Minadh Dhalal. Libanon: Beirut, tt.

Al-Hujwiri. Kasyful Mahjub. Terj. Suwardjo Muthary dan Abdul Hadi. Bandung: Mizan, 1992.

al-Jilani, Abdul Qadir. Titian Mahabbah. Terj. Ahmad Fadhil. Jakarta: Sahara, 2003.

al-Qusyairy, Imam. Al-Risalah Al-Qusyairiyyah Fi Ilmi al-Tashawwuf. Beirut: Darul Khair, tt.

An-Najar, Amir. Psikoterapi Sufisti., Terj. Ija Suntana. Jakarta: Hikmah, 2004.

as-Sarraj, Abu Nashr. Al-Luma'. Terj. Wasmukan dan Samson Rahman. Surabaya:

Risalah Gusti.

Frager, Robert. Hati, Diri, Jiwa. Terj. Hasmiyah Rauf. Jakarta: Serambi, 1999.

Gulen, Muhammad Fethullah. Tasawuf Untuk Kita Seтиa Terj. Fuad Syaifuddin Nur. Jakarta: Republika, 2013.

Hamka. Tasawuf. Jakarta: Pustaka Panjimas, 1993.

Jami, Maulana 'Abd ar-Rahman. Ensiklopedi Tokoh Sufi. Terj. Kamran Asad Irsyadi dan Mata Nasrullah. Yogyakarta: Beranda, 2007.

Kabbani, Muhammad Hisyam. Tasawuf dan Ihsan. Terj. Zaimul Am. Jakarta: Serambi, 2007.

Khaldun, Ibn. Muqaddimah. Beirut-Libanon: Dar Al-Kotob Al-ilmiyah, 2003.

Nasr, Seyyed Hossein (ed.), Insiklopedi Tematis Spiritualitas Islam Manifestasi. Terj. M. Solihin Arianto, dkk. Bandung: Mizan, 2003.

Nasution, Harun. Falsafah dan Mistisisme dalam Islam. Jakarta: Bulan Bintang, 1973.

Schimmel, Annemarie. Dimensi Mistik Dalam Islam. Terj. Sapardi Djoko Damono, dkk. Jakarta: Pustaka Firdaus, 2000.

Shah, Idries. Mahkota Sufi. Terj. Hidayatullah \& Roudlon. Surabaya: Risalah Gusti, 2000.

Trimingham, J. Spencer. The Sufi Order In Islam. New York:Oxford University Press, 1971. 